\title{
Corn silage supplementation for dairy cows grazing annual ryegrass at two pasture allowances
}

[Suplementação com silagem de milho para vacas leiteiras manejadas em duas ofertas diárias em pastagens de azevém anual]

M.F. Miguel ${ }^{1}$, R. Delagarde ${ }^{2}$, H.M.N. Ribeiro-Filho ${ }^{1^{*}}$

${ }^{1}$ Universidade do Estado de Santa Catarina - Lages, SC

${ }^{2}$ Physiologie, Environnement et Génétique pour l'Animal et les Systèmes d'Elevage (PEGASE) - INRA - Saint-Gilles, France

\begin{abstract}
Corn silage supplementation for dairy cows grazing in temperate annual pastures has rarely been investigated. The aim of this study is to compare two supplementation levels $(0$ and $4 \mathrm{~kg}$ dry matter $[\mathrm{DM}] /$ day of a 7:1 mixture of corn silage and soybean meal) in dairy cows strip-grazing annual ryegrass (Lolium multiflorum Lam.) at two pasture allowances (PA, low $=25$ and high $=40 \mathrm{~kg} \mathrm{DM} / \mathrm{d}$ at ground level). The study was carried out according to an incomplete $4 \times 3$ Latin square design, using 12 cows and three experimental periods of 12 days. The green leaves allowances were only 4.9 and $8.5 \mathrm{~kg} D M / \mathrm{d}$ at the low and high PA, respectively. The total DM intake and milk production increased in supplemented cows compared to un-supplemented cows at the low PA, but were similar between supplementation levels at the high PA. The PI was unaffected by the PA, whereas the substitution rate was 0.68 in cows at the low PA and 1.35 in cows at the high PA. Corn silage supplementation may improve the total DM intake and milk production of dairy cows grazing in temperate annual pastures, but only at a low PA.
\end{abstract}

Keywords: dairy cow, corn silage, grazing, pasture allowance, supplementation

\section{RESUMO}

O objetivo deste estudo foi comparar os efeitos de dois níveis de suplementação ( 0 e $4 \mathrm{~kg}$ de matéria seca [MS]/dia de uma mistura de silagem de milho e farelo de soja na razão de 7:1) para vacas leiteiras em pastos de azevém anual (Lolium multiflorum Lam.) manejados em faixas diárias com duas ofertas (OF, baixa $=25$ e alta $=40 \mathrm{~kg}$ de MS/dia medidas em nível do solo). Os tratamentos foram comparados em delineamento quadrado latino incompleto $4 \times 3$, com 12 vacas em três períodos de 12 dias. A oferta de folhas foi somente de 4,9 e 8,5kg de MS/dia nas OF baixa e alta, respectivamente. O consumo total de MS e a produção de leite aumentaram com a suplementação somente quando os animais estavam em baixa $O F$, não havendo efeito da suplementação em alta OF. $O$ consumo do pasto não foi afetado pela OF, entretanto a taxa de substituição foi de 0,68 em baixa OF e de 1,35 em alta OF. A suplementação com silagem de milho promove o aumento do consumo total de MS e da produção de leite de vacas manejadas em pastos anuais de clima temperado somente em situações de baixa $\mathrm{OF}$.

Palavras-chave: vacas leiteiras, silagem de milho, pastejo, oferta, suplementação

\section{INTRODUCTION}

Annual ryegrass (Lolium multiflorum Lam.) is a major forage species used during the winter in dairy systems in many subtropical regions, where annual forage species are useful in mixed crop-

Recebido em 21 de fevereiro de 2017

Aceito em 16 de outubro de 2018

* Autor para correspondência (corresponding author)

E-mail: henrique.ribeiro@udesc.br livestock systems. These systems produce half of the world's food (Herrero et al., 2010) and are considered more profitable and sustainable than specialized production systems (Russele et al., 2007). Some additional reasons for using annual ryegrass is that ryegrass has a high nutritional value and that it has the potential to reseed naturally (Barth Neto et al., 2013). 
In these systems, corn silage supplementation can be a tool for increasing the stocking rate and milk production per hectare (Moate et al., 1984; Phillips, 1988). The effects of silage supplementation during grazing on milk production in individual cows are variable and unclear. This is because the milk production response (MR -increase in milk production per kilogram of supplemental dry matter [DM] intake) is dependent on the substitution rate (SR reduction in pasture DM intake [PI] per kilogram of DM supplement intake) (Phillips, 1988), which is the result of many interactions between pasture management, pasture traits, and supplement characteristics (Moate et al., 1984; Phillips, 1988; Delagarde et al., 2011).

The SR for cows fed on pasture and a foragebased supplement can vary from 0.3 to $1.1 \mathrm{~kg}$ $\mathrm{DM} / \mathrm{kg}$ DM depending on their level of pasture allowance (PA), which affects the MR and total DM intake (Phillips, 1988; Delagarde et al., 2011). Nevertheless, even at a high PA, relatively low SRs have been described in the case of low pasture mass (Stockdale, 1996; Miguel et al., 2014). This occurs because a low pre-grazing pasture mass may in itself restrict the PI independently of the PA. Considering that low pasture mass is commonly observed in annual ryegrass pastures, especially in the first grazing cycles following sowing (Miguel et al., 2014), studies to evaluate the SR and MR as a function of grazing management are necessary to better predict the nutritional advantages of corn silage supplementation for grazing dairy cows.

We hypothesized that, even with low pasture mass, any increase in the PA would increase the $\mathrm{SR}$ and reduce the MR in dairy cows. The aim of this study was to investigate the effect of corn silage supplementation on dairy cows grazing on annual ryegrass pasture by measuring the MR and total DM intake at two contrasting levels of PA.

\section{MATERIALS AND METHODS}

A $2 \times 2$ factorial design was utilized, with two PA levels (low $=25$ and high $=40 \mathrm{~kg} D M /$ day above ground level) and two supplementation levels ( 0 and $4 \mathrm{~kg} \mathrm{DM} /$ day). The four treatments were compared on lactating dairy cows grazing on annual ryegrass (Lolium multiflorum cv. Common). The supplement was a 7:1 mixture based on the DM of corn silage and soybean meal, which was balanced such that the rumen microbial protein synthesis (EMPS) was not limited, as recommended by the INRA (Alimentation..., 2007). The chemical composition and energetic value of the supplements are presented in Table 1.

The supplement was offered individually twice daily after morning and afternoon milkings, for $60 \mathrm{~min}$ at a time ( $2 \mathrm{~h} / \mathrm{day})$. After this time, the remaining supplement was considered refusals and removed from the barn. During the periods of supplement feeding, the un-supplemented cows were on pasture. The treatments were compared according to an incomplete $4 \times 3$ Latin square design replicated three times and balanced for carryover effects (Jones and Kenward, 1989). Each experimental period was 12 days, with an 8-day adaptation period and a 4-day measurement period.

Table 1. Chemical composition and nutritive value of supplements

\begin{tabular}{|c|c|c|}
\hline Item & $\begin{array}{c}\text { Supplemen } \\
\mathrm{t}\end{array}$ & \\
\hline & Corn silage & $\begin{array}{c}\text { Soybean } \\
\text { meal }\end{array}$ \\
\hline Dry matter $(\mathrm{g} / \mathrm{kg})$ & 303 & 878 \\
\hline \multicolumn{3}{|l|}{$\begin{array}{l}\text { Chemical Composition } \\
\text { (g/kg DM) }\end{array}$} \\
\hline Organic matter & 951 & 942 \\
\hline Crude protein & 54 & 492 \\
\hline Neutral detergent fiber & 533 & 163 \\
\hline Acid detergent fiber & 251 & 88 \\
\hline \multicolumn{3}{|l|}{ Nutritive value } \\
\hline $\mathrm{NE}_{\mathrm{L}}(\mathrm{MJ} / \mathrm{kg} \mathrm{DM})^{1}$ & 6.2 & 8.5 \\
\hline
\end{tabular}

${ }^{1}$ Net energy for lactation estimated according to INRA (Alimentation..., 2007).

Twelve multiparous Holstein dairy cows were separated into four homogeneous groups according to milk production $(22.1 \pm 5.4 \mathrm{~kg} / \mathrm{day})$, lactation stage $(129 \pm 61$ DIM) and live weight $(591 \pm 115 \mathrm{~kg})$ measured one week before the start of the experiment. Two weeks before the start of the experiment and between experimental periods, cows grazed as one herd on nonexperimental pastures of annual ryegrass and were supplemented daily with $4 \mathrm{~kg}$ corn silage DM and $0.6 \mathrm{~kg}$ soybean meal DM. Cows were milked twice daily at 0730 and $1600 \mathrm{~h}$ throughout the experiment. 
The study was performed in $\left(50^{\circ} 18^{\prime} 26^{\prime \prime} \mathrm{W}, 27^{\circ}\right.$ $47^{\prime} 4 " \mathrm{~S}$ and $920 \mathrm{~m}$ in altitude). The experiment was conducted in the winter and spring from 25 August to 11 October, 2012. The ryegrass pastures were seeded after the corn crop harvest (Zea mays) on May 02, 2012. Thirty days before the start of the trial and immediately after each grazing cycle, the experimental area was fertilized with $50 \mathrm{~kg}$ of $\mathrm{N} / \mathrm{ha}$, supplied as ammonium nitrate. One uniform area including paddock 1 (2.4 ha) and paddock 2 (5.0 ha) was used for the experiment. For the first period, paddock 1 was split into four sub-paddocks, one for each group. Paddock 2 was divided into 8 sub-paddocks, and each one was assigned to one experimental treatment in the second or third period. The grazing method was strip-grazing, and the daily allocated area for each treatment group was calculated from a daily estimate of pre-grazing pasture mass (see Feed and Measurements section) to allow 25 or $40 \mathrm{~kg}$ DM/cow, according to the treatment. Fresh pasture was allocated once daily after morning milking, and the daily allocated area was adjusted by means of electric fences. Water and minerals were continually available at grazing.

Milk production was recorded for each cow at each milking. The milk fat concentration and milk protein concentration were measured on the four last days of each period by infrared spectrophotometry (International IDF Standard 141C: 2000). The live weight was measured at the beginning and end of each experimental period.

The individual PI was measured on the four last days of each period using the $n$-alkane technique (Mayes et al., 1986) with the ratio of pasture $C_{31}$ (hentriacontane) to dosed $\mathrm{C}_{32}$ (dotriacontane). Throughout each period, all cows were dosed after morning and afternoon milking with a cellulose stopper (Carl Roth, GmbH, Karlsruhe, Germany) containing $164 \mathrm{mg}$ of $\mathrm{C}_{32}$, beginning on day 1 . During the 4 days of measurements, fecal grab samples were collected from each cow after each milking. The feces were oven-dried at $60^{\circ} \mathrm{C}$ for at least $72 \mathrm{~h}$, then composited by period and cow, and ground through a 1-mm screen for subsequent chemical analyzes. The pasture samples were collected on days 9 and 11 as described in the following section.
The net energy balance was calculated as the ratio between the $\mathrm{NE}_{\mathrm{L}}$ supply (MJ/day) and the $\mathrm{NE}_{\mathrm{L}}$ requirements (MJ/day), according to the INRA (2007). The $\mathrm{NE}_{\mathrm{L}}$ requirements for lactation and maintenance were calculated from 4\%-fat corrected milk (FCM) production and live weight, respectively. The $\mathrm{NE}_{\mathrm{L}}$ supply was calculated from the pasture, silage and soybean meal DM intake and the $\mathrm{NE}_{\mathrm{L}}$ concentrations of each feed, accounting for the negative digestive interactions between the concentrate and forages (Alimentation..., 2007).

The daily grazing pattern was measured individually by visual observations of trained observers every $10 \mathrm{~min}$ for $24 \mathrm{~h}$ on days 10 and 12. Daily grazing time was calculated as the number of grazing observations multiplied by 10 . The pasture intake rate (g DM/min) was calculated by dividing the daily PI (kg DM) by the daily grazing time (min). No behavior was recorded indoors when the cows were milked or fed the supplement.

The amounts of corn silage and soybean meal individually offered and refused were weighed at each meal and subsampled from days 9 to 12 for each experimental period. All samples were oven-dried for $72 \mathrm{~h}$ at $60^{\circ} \mathrm{C}$ and ground through a 1 -mm screen for subsequent chemical analyzes.

A rising plate meter (Farmworks ${ }^{\circledR}$, F200 model, New Zealand) was used to estimate the pre- and post-grazing pasture mass as an indirect method ('T Mannetje, 2000). On day 7 of each period, five points per treatment - from the lowest to highest point in the pasture - were cut at ground level with scissors in the plate area $\left(0.1 \mathrm{~m}^{2}\right)$ after the height measurement. After manual removal of soil and roots, the samples were dried in an oven for $72 \mathrm{~h}$ at $60^{\circ} \mathrm{C}$. One equation was generated for each period and was used to calculate the PA during measurements days (day 9 to day 12). In periods of adaptation, the pregrazing pasture mass was calculated with the equations generated by Miguel et al. (2012, 2014) at same experimental station. For analytical purposes, pasture mass was recalculated with all measurements per period, using one equation to estimate the pre-grazing pasture mass and one equation to estimate the post-grazing pasture mass, as follows: 
Pre-grazing PM $(\mathrm{kg} \mathrm{DM} / \mathrm{ha})=107+75( \pm 5.1) \times$ pre-grazing sward height $(\mathrm{cm})\left(\mathrm{n}=60, \mathrm{R}^{2}=0.83\right.$, $\mathrm{SD}=421)$

Post-grazing pasture PM (kg DM/ha) $=101+72$ $( \pm 5.2) \times$ post-grazing sward height $(\mathrm{cm})(\mathrm{n}=60$, $\mathrm{R}^{2}=0.80, \mathrm{SD}=426$ )

The pre-grazing extended height of the tiller (upper lamina) and of its highest sheath were measured on 100 tillers per treatment taken at random on days 9 and 11 . The post-grazing tiller and sheath extended heights were measured on days 10 and 12 on 200 tillers taken at random per treatment.

The morphological and chemical compositions of the sward for each treatment were determined on days 9 and 11 at each period. Twenty handfuls of randomly selected herbage $(\sim 800 \mathrm{~g}$ fresh) were cut with scissors at ground level and stored at in a freezer $\left(-20^{\circ} \mathrm{C}\right)$, carefully maintaining the vertical structure of the pasture. After this, the sward was cut at the average postgrazing extended tiller height of the corresponding treatment, with the objective to maintain the representative pasture selected by the grazing cows. The upper part was separated into two subsamples. One subsample was dried in an oven for $72 \mathrm{~h}$ at $60^{\circ} \mathrm{C}$ with forced ventilation and stored for chemical analyzes. The other subsample was used for morphological classification (ryegrass only). Annual ryegrass composed $98 \%$ of the pasture available to cows. The ryegrass was separated into green leaves, stems + pseudostems and dead tissues, if any. Each constituent was dried in an oven for $72 \mathrm{~h}$ at $60^{\circ} \mathrm{C}$ to determine the morphological composition on a DM basis.

Samples were combusted to ash in a muffle furnace at $550^{\circ} \mathrm{C}$ for $4 \mathrm{~h}$, and the organic matter $(\mathrm{OM})$ was determined by mass difference. Total $\mathrm{N}$ was assayed using the Kjeldahl method (Method 984.13; Official..., 1997). The neutral detergent fiber (NDF) concentration was assessed according to Mertens (2002), except that the samples were weighed into filter bags and treated with neutral detergent using ANKOM equipment (ANKON Technology, Macedon NY, USA). This analysis included $\alpha$ amylase, but did not include sodium sulfite. The concentration of acid detergent fiber (ADF) was analyzed according to Method 973.18 of the AOAC (Official..., 1997) after the NDF analyses. N-alkanes were determined according to Mayes et al. (1986). The net energy concentration of feeds was calculated from their chemical composition according to the INRA (Alimentation...., 2007).

The animal data averaged per cow and period $(n=32)$ were analyzed using PROC MIXED in the SAS (Statistical Analysis System, 1999) using the following model:
$\mathrm{Y}_{\mathrm{ijkl}}=\mu+\operatorname{cow}_{\mathrm{i}}+$ period $_{\mathrm{j}}+$ pasture allowance $_{\mathrm{k}}+$ supplementation level $_{1}+$ [pasture allowance ${ }_{\mathrm{k}} \times$ supplementation level $]+e_{\mathrm{ijkl}}$;

where $\mathrm{Y}_{\mathrm{ijkl}}, \mu, \operatorname{cow}_{\mathrm{i}}$, period $\mathrm{j}_{\mathrm{j}}$, pasture allowance $\mathrm{k}_{\mathrm{k}}$ supplementation level $\mathrm{l}_{1}$, [pasture allowance $\mathrm{k}_{\mathrm{k}} \times$ supplementation level $l_{1}$ and $e_{\mathrm{ijkl}}$ represent, respectively, the analyzed variable, the overall mean, the random effect of the cow, the random effect of the period, the fixed effect of PA, the fixed effect of supplementation, the fixed effect of the interaction allowance $\mathrm{k}_{\mathrm{k}} \times$ supplementation $_{\mathrm{l}}$ and the residual error.

The pasture data averaged per treatment and period $(n=12)$ was analyzed using PROC GLM in the Statistical Analysis Systems (Statistical..., 1999) using the following model:

$\mathrm{Y}_{\mathrm{jkl}}=\mu+$ period $_{\mathrm{j}}+$ pasture allowance $_{\mathrm{k}}+$ supplementation level $l_{1}+$ [pasture allowance k $_{\mathrm{k}} \times$ supplementation level $]+e_{\mathrm{jk} l}$;

where $\mathrm{Y}_{\mathrm{ijkl}}, \mu$, period ${ }_{\mathrm{j}}$, pasture allowance $_{\mathrm{k}}$, supplementation level $\mathrm{l}_{\mathrm{l}}$, [pasture allowance $_{\mathrm{k}} \times$ supplementation level $\left.{ }_{1}\right]$ and $e_{\mathrm{ijkl}}$ represent, respectively, the analyzed variable, the overall mean, the fixed effect of the period, the fixed effect of PA, the fixed effect of supplementation, the fixed effect of the interaction allowance $_{k} \times$ supplementation $_{1}$ and the residual error.

\section{RESULTS}

There was no interaction between pasture allowance and supplementation level for any of the pasture characteristics or for grazing management (Table 2). The pre-grazing pasture mass and plate meter sward height were similar between treatments averaging $1,902 \mathrm{~kg} \mathrm{DM} / \mathrm{ha}$ and $12 \mathrm{~cm}$, respectively. The extended sheath height averaged 0.71 of the extended tiller height. The post-grazing pasture mass and post- 
grazing extended sheath and lamina height did not differ with supplementation level, but were lower by 13,16 and $33 \%$ at the low PA compared with the high PA, respectively. The green leaves allowance was similar between supplementation levels and increased from 4.9 to $8.5 \mathrm{~kg} \mathrm{DM} / \mathrm{d}$ from the low to high PA. The postgrazing extended sheath height, compared with pre-grazing extended sheath height, decreased by 9.0 and $6.0 \mathrm{~cm}$ at the low and high PA, respectively. The crude protein and neutral detergent fiber of the selected pasture were similar between treatments, averaging 140 and $567 \mathrm{~g} / \mathrm{kg}$ DM, respectively. The net energy value of the selected pasture averaged $6.3 \mathrm{MJ} \mathrm{NE} / \mathrm{kg}$ DM.

Table 2. Effects of pasture allowance (PA) and corn silage supplementation (S) on pre- and post-grazing pasture characteristics, grazing management and chemical composition of selected pasture by dairy cows grazing on annual ryegrass (Lolium multiflorum Lam.)

\begin{tabular}{|c|c|c|c|c|c|c|c|c|}
\hline \multirow[t]{2}{*}{ Item } & \multicolumn{2}{|c|}{ Low PA } & \multicolumn{2}{|c|}{ High PA } & \multirow[t]{2}{*}{$\mathrm{RSD}^{1}$} & \multicolumn{3}{|c|}{$P$ - value } \\
\hline & $0^{2}$ & $4^{2}$ & $0^{2}$ & $4^{2}$ & & PA & $\mathrm{S}$ & $\mathrm{PA} \times \mathrm{S}$ \\
\hline \multicolumn{9}{|l|}{ Pasture mass (kg DM/ha) } \\
\hline Pre-grazing & 1796 & 1946 & 1910 & 1955 & 123 & 0.427 & 0.219 & 0.496 \\
\hline Post-grazing & 1134 & 1169 & 1327 & 1325 & 97.9 & 0.021 & 0.775 & 0.755 \\
\hline \multicolumn{9}{|l|}{$\begin{array}{l}\text { Pre-grazing sward } \\
\text { height }(\mathrm{cm})\end{array}$} \\
\hline Rising plate meter & 11.5 & 12.0 & 12.2 & 12.3 & 1.14 & 0.508 & 0.633 & 0.732 \\
\hline Extended tiller & 42.3 & 44.4 & 45.6 & 44.8 & 1.38 & 0.055 & 0.430 & 0.124 \\
\hline Extended sheath & 30.1 & 31.6 & 32.6 & 32.0 & 1.34 & 0.116 & 0.587 & 0.211 \\
\hline Extended lamina $^{3}$ & 12.1 & 12.7 & 13.0 & 12.9 & 0.41 & 0.076 & 0.301 & 0.205 \\
\hline \multicolumn{9}{|l|}{ Post-grazing sward height (cm) } \\
\hline Rising plate meter & 7.1 & 7.5 & 8.3 & 8.4 & 0.71 & 0.039 & 0.593 & 0.654 \\
\hline Extended tiller & 25.6 & 26.7 & 31.4 & 33.6 & 3.27 & 0.015 & 0.419 & 0.770 \\
\hline Extended sheath & 21.6 & 22.5 & 25.6 & 27.0 & 2.14 & 0.014 & 0.403 & 0.850 \\
\hline Extended lamina $^{3}$ & 4.0 & 4.2 & 5.7 & 6.6 & 1.15 & 0.021 & 0.445 & 0.589 \\
\hline \multicolumn{9}{|l|}{ Pasture allowance (kg DM/d) } \\
\hline Above ground level & 25.0 & 24.9 & 39.9 & 39.8 & 0.08 & 0.001 & 0.180 & 0.483 \\
\hline Green material $^{4}$ & 22.5 & 24.1 & 38.6 & 38.6 & 1.42 & 0.001 & 0.380 & 0.396 \\
\hline Leaves & 4.9 & 4.9 & 8.6 & 8.4 & 1.84 & 0.014 & 0.951 & 0.951 \\
\hline Offered area $\left(\mathrm{m}^{2} / \mathrm{cow} / \mathrm{d}\right)$ & 142 & 130 & 210 & 207 & 8.94 & 0.001 & 0.186 & 0.439 \\
\hline \multicolumn{9}{|l|}{$\begin{array}{l}\text { Chemical composition } \\
\text { (g/kg DM) }\end{array}$} \\
\hline Dry matter $(\mathrm{g} / \mathrm{kg})$ & 263 & 265 & 268 & 275 & 13.4 & 0.399 & 0.586 & 0.784 \\
\hline Organic matter & 941 & 940 & 942 & 940 & 5.2 & 0.912 & 0.675 & 0.826 \\
\hline Crude protein & 134 & 139 & 141 & 145 & 14.1 & 0.483 & 0.580 & 0.919 \\
\hline Neutral detergent fiber & 569 & 566 & 578 & 556 & 23.3 & 0.979 & 0.383 & 0.505 \\
\hline Acid detergent fiber & 284 & 285 & 293 & 276 & 19.0 & 1.000 & 0.515 & 0.433 \\
\hline Energetic value (MJ/kg DM) & 6.31 & 6.31 & 6.27 & 6.46 & 0.28 & 0.774 & 0.582 & 0.582 \\
\hline $\begin{array}{l}\text { Low PA= 25kg DM/d, High PA = } \\
{ }^{1} \text { Residual standard deviation. } \\
{ }^{2} \text { Level of supplementation: } 0=0 \mathrm{k} \\
{ }^{3} \text { Difference between extended till }\end{array}$ & $\mathrm{g} \mathrm{DM} / \mathrm{d}$ & 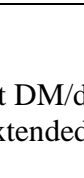 & & & & & & \\
\hline
\end{tabular}

The DM supplement intake was lower than expected, averaging $2.0 \mathrm{~kg} \mathrm{DM} /$ day (i.e., approximately $50 \%$ of supplement offered), with slightly more refusals at the high than at the low PA (Table 3). The pasture DM intake was unaffected by the PA, but was lower by $2.0 \mathrm{~kg}$ $\mathrm{DM} /$ day in supplemented than in un- supplemented cows. The total DM intake, milk production and milk protein production increased with silage supplementation at the low PA and were similar between supplemented and unsupplemented cows at the high PA (interaction: $\mathrm{P}<0.05)$. The $\mathrm{NE}_{\mathrm{L}}$ supply, FCM production and milk fat production increased with 
supplementation at the low PA and decreased with supplementation at the high PA (interaction: $\mathrm{P}<0.05$ ). The milk protein concentration and live weight were similar between treatments averaging $34.5 \mathrm{~g} / \mathrm{kg}$ and $559 \mathrm{~kg}$, respectively. The grazing time in the afternoon and daily grazing time decreased, respectively, by 37 and $59 \mathrm{~min}$ in supplemented cows compared with un- supplemented cows. The grazing time in the morning had a tendency to be highest in unsupplemented cows at the low PA when compared with other treatments (interaction: $\mathrm{P}=$ 0.064). The pasture intake rate decreased by 1.7 and $4.1 \mathrm{~g} \mathrm{DM} / \mathrm{min}$ in supplemented cows compared with un-supplemented cows at the low and high PA, respectively (interaction: $\mathrm{P}<0.05$ ).

Table 3. Effects of pasture allowance (PA) and corn silage supplementation (S) on dry matter intake (DMI), energy balance, milk production, milk composition, and grazing behavior of dairy cows stripgrazing annual ryegrass (Lolium multiflorum Lam.)

\begin{tabular}{|c|c|c|c|c|c|c|c|c|}
\hline \multirow[t]{2}{*}{ Item } & \multicolumn{2}{|c|}{ Low PA } & \multicolumn{2}{|c|}{ High PA } & \multirow[t]{2}{*}{$\mathrm{RSD}^{1}$} & \multicolumn{3}{|c|}{$P$-value } \\
\hline & $0^{2}$ & $4^{2}$ & $0^{2}$ & $4^{2}$ & & PA & $\mathrm{S}$ & $\mathrm{PA} \times \mathrm{S}$ \\
\hline \multicolumn{9}{|l|}{ Dry matter intake (kg/d) } \\
\hline Pasture & 8.10 & 6.51 & 8.60 & 6.20 & 0.755 & 0.712 & $<0.001$ & 0.165 \\
\hline Corn silage & & 2.05 & & 1.55 & 0.358 & 0.049 & $<0.001$ & 0.101 \\
\hline Soybean meal & & 0.29 & & 0.22 & 0.051 & 0.049 & $<0.001$ & 0.101 \\
\hline Total & $8.09^{b}$ & $8.85^{\mathrm{a}}$ & 8.54 & 7.98 & 0.749 & 0.462 & 0.718 & 0.027 \\
\hline $\mathrm{NE}_{\mathrm{L}}$ balance ${ }^{3}$ & 0.69 & 0.66 & 0.62 & 0.59 & 0.086 & 0.039 & 0.374 & 0.968 \\
\hline Milk production $(\mathrm{kg} / \mathrm{d})$ & $13.2^{\mathrm{b}}$ & $15.9^{\mathrm{a}}$ & $16.3^{\mathrm{a}}$ & $14.7^{\mathrm{a}}$ & 2.44 & 0.296 & 0.572 & 0.027 \\
\hline $4 \%$ FCM production $(\mathrm{kg} / \mathrm{d})$ & $11.6^{\mathrm{b}}$ & $15.1^{\mathrm{a}}$ & $15.5^{\mathrm{a}}$ & $13.0^{\mathrm{b}}$ & 2.66 & 0.367 & 0.612 & 0.007 \\
\hline Milk fat concentration (g/kg) & 33.0 & 36.1 & 36.1 & 32.9 & 3.59 & 0.984 & 0.953 & 0.028 \\
\hline Milk protein concentration $(\mathrm{g} / \mathrm{kg})$ & 34.5 & 34.6 & 34.3 & 34.5 & 1.03 & 0.748 & 0.736 & 0.896 \\
\hline \multicolumn{9}{|l|}{ Grazing time ( $\mathrm{min})$} \\
\hline Total & 561 & 491 & 537 & 494 & 37.4 & 0.450 & 0.001 & 0.321 \\
\hline Morning (0600-1200 h) & 177 & 159 & 156 & 158 & 13.4 & 0.027 & 0.098 & 0.064 \\
\hline Afternoon (1200-1800 h) & 187 & 155 & 198 & 156 & 11.6 & 0.202 & $<0.001$ & 0.249 \\
\hline Evening (1800-2400 h) & 99.0 & 109.0 & 90.7 & 89.0 & 23.59 & 0.108 & 0.635 & 0.524 \\
\hline Night (2400-0600 h) & 97.5 & 67.2 & 91.8 & 92.2 & 21.71 & 0.229 & 0.069 & 0.070 \\
\hline Pasture intake rate (g DM/min) & 14.6 & 12.8 & 16.2 & 12.2 & 1.35 & 0.301 & $<0.001$ & 0.031 \\
\hline $\begin{array}{l}\text { Low PA= } 25 \mathrm{~kg} \mathrm{DM} / \mathrm{d} \text {, High PA }= \\
\text { by same letters into the same PA a } \\
{ }^{1} \text { Residual standard deviation. } \\
{ }^{2} \text { Supplementation level: } 0=0 \mathrm{~kg} \text { of } \\
{ }^{3} \mathrm{NE}_{\mathrm{L}} \text {, net energy for lactation (pro }\end{array}$ & $k g \mathrm{DN}$ & $\begin{array}{l}\text { d; Whes } \\
\text { ent. }\end{array}$ & inter & on PA & is sigr & & & ollowec \\
\hline
\end{tabular}

\section{DISCUSSION}

The aim of this study was to investigate the effect of corn silage supplementation on the total DM intake and milk production of dairy cows grazing annual ryegrass at two levels of PA in annual ryegrass pastures characterized by low pre-grazing pasture mass $(<2,000 \mathrm{~kg} \mathrm{DM} / \mathrm{ha})$. The low pre-grazing pasture mass in annual ryegrass was a consequence of poor tiller density and pasture bulk density due to the short time between sowing and the entrance of cows into the pasture at the first grazing cycle. Annual ryegrass pastures have a lower average pasture bulk density than perennial ryegrass pastures
(210 vs. $317 \mathrm{~kg}$ DM/ha/cm; Ribeiro-Filho et al., 2005, 2009; Miguel et al., 2012), but pastures with a bulk density averaging only $157 \mathrm{~kg}$ $\mathrm{DM} / \mathrm{ha} / \mathrm{cm}$ have also been found (Miguel et al., 2014). In the present study, the pasture bulk density averaged $159 \mathrm{~kg} \mathrm{DM} / \mathrm{ha} / \mathrm{cm}$, which indicates that the pasture mass was most likely also low and probably the result of poor tiller density (which was not measured).

The energetic value of the selected pasture ranged between 6.0 and $6.4 \mathrm{MJ} \mathrm{NE}_{\mathrm{L}} / \mathrm{kg} \mathrm{DM}$, which is indicative of pastures at a low to medium quality (Peyraud and Delagarde, 2013). The low-to-medium pasture quality was 
associated with a CP content lower than $150 \mathrm{~g} / \mathrm{kg}$ and $\mathrm{a}$ DM and NDF content greater than $550 \mathrm{~g} / \mathrm{kg}$ DM, which was a consequence of having a small proportion of leaves on the grazing layer. This factor may be explained by the high elongation rate of annual ryegrass tillers and the presence of plants growing by self-seeding. Annual ryegrass pastures use an increasing elongation rate to compensate for poor tiller density (Duchini et al., 2014) and are able to re-establish annually by self-seeding (Barth Neto et al., 2014). Plants reestablished by self-seeding present reproductive tillers much earlier than those sown in the year of utilization, decreasing the pasture's nutritive value. In this study, the pasture had many more reproductive tillers (which was noted through visual observation, though not quantified) and the proportion of sheaths present was $20 \%$ greater than that observed in a previous experience conducted in the same area (Miguel et al., 2014).

The low PI observed at the high PA and the lack of effect on the PI from changes in the PA may be at least partially explained by severe grazing conditions. These conditions were a consequence of low pre-grazing pasture mass and low dry matter of green leaves (DMGL) allowance $(<10 \mathrm{~kg} \mathrm{DM} /$ day $)$, which are two well-known factors that limit intake even at a high PA (Delagarde et al., 2001; Miguel et al., 2014). Delagarde et al. (2001) have shown in a literature review that the PI is more strongly related to the DMGL allowance than to the total DM allowance. These authors found that when the DMGL allowance was lower than $10 \mathrm{~kg}$ $\mathrm{DM} /$ day, as it was in our experiment, this should result in a PI of approximately $8 \mathrm{~kg} \mathrm{DM} /$ day. In the present study, the PI observed in cows grazing at a high PA without supplementation was close to $8.6 \mathrm{~kg} /$ day for a DMGL allowance of less than $9 \mathrm{~kg} /$ day. Similarly, Ribeiro-Filho et al. (2009) observed that dairy cows grazing annual ryegrass increased the PI from 11.9 to $16.6 \mathrm{~kg}$ when the DMGL increased from 8.8 to $12 \mathrm{~kg}$ /day (24 to $37 \mathrm{~kg}$ of total DM/day), with a defoliation depth of sheaths not higher than $3.5 \mathrm{~cm}$. In the current study, the defoliation depth of sheaths was $9.0 \mathrm{~cm}$ at the low PA and $6.0 \mathrm{~cm}$ at the high PA, supporting the idea that, even at the high PA, cows need to graze on the sward layers, which are rich in sheaths and poor in leaves. The role of sheaths in increasing harvest pasture difficulties, which limits the PI, has been described in previous literature (Delagarde et al., 2001).

The PI rate and the daily grazing time observed also provided evidence of severe grazing conditions. It is known that as grazing severity increases, the daily grazing time generally increases and the PI rate generally decreases in dairy cows grazing either annual (Ribeiro-Filho et al., 2011) or perennial ryegrass (Barrett et al., 2001). When the PA is estimated at ground level (as in the present work), values of the PI rating close to $16 \mathrm{~g} \mathrm{DM} / \mathrm{min}$ have been found in the lowest threshold of the existing literature, and a daily grazing time close to $545 \mathrm{~min}$ has been found to be the highest threshold in the existing literature (Pérez-Prieto and Delagarde, 2012). In the present study, un-supplemented cows showed an average PI rate of $15 \mathrm{~g} \mathrm{DM} / \mathrm{min}$ and a daily grazing time of $550 \mathrm{~min}$. This low PI rate and high daily grazing time show grazing difficulties.

The lack of effect of the PA changes on milk production was a consequence of a similar PI being present at both levels of the PA. Average milk production was drastically affected by this low PI. Considering milk production two weeks before the start of the experiment $(22 \mathrm{~kg} /$ day $)$ and assuming a theoretical persistence of $98 \%$ per week (Delaby et al., 1999), the expected milk production (eMP, $\mathrm{kg} /$ day) at the mid-point of the experiment (after a 4 week delay) would have been, on average, $19.6 \mathrm{~kg} /$ day. This value is close to that observed in a previous experiment that used dairy cows from the same herd, which were at a similar lactation stage and were grazing annual ryegrass without supplementation (Ribeiro-Filho et al., 2009). In the current study, milk production observed at the high PA without supplementation was less than $16.5 \mathrm{~kg} / \mathrm{d}$. Consequently, the $\mathrm{NE}_{\mathrm{L}}$ supply averaged only 0.6 of the $\mathrm{NE}_{\mathrm{L}}$ requirements, supporting the low feeding level observed in this experiment.

The observation that DM corn silage intake was lower than expected may be at least partially explained by the nutritive value of corn silage. Substantial amounts of supplement refusals have already been observed (Miguel et al., 2014) in cases where the nutritive value of the silage was similar to or lower than that of grazed pasture. Similarly, grazing cows refused more corn silage in the spring than in the autumn, due to the higher nutritive value of the selected pasture in 
spring (Hernandez-Mendo and Leaver, 2004). In the present study, the $\mathrm{CP}$ content and the $\mathrm{NE}_{\mathrm{L}}$ of the selected pasture at the high PA were $142 \mathrm{~g} / \mathrm{kg}$ $\mathrm{DM}$ and $6.4 \mathrm{MJ} / \mathrm{kg} \mathrm{DM}$, respectively, whereas the supplement showed a lower $\mathrm{CP}$ content $(111 \mathrm{~g} / \mathrm{kg} \mathrm{DM})$ and similar $\mathrm{NE}_{\mathrm{L}}(6.5 \mathrm{MJ} / \mathrm{kg} \mathrm{DM})$. Compared with the values put forth by the INRA (Alimentation..., 2007), the nutritive value of the corn silage used in the present study was similar to that obtained from corn growing under poor vegetation conditions.

The observation that the SR was smaller at the low PA than at the high PA, with a positive MR (+0.18kg of milk per kg DM of supplement), was relatively expected, because it is known that decreasing the PA also decreases the SR, which increases the total DM intake and MR (Phillips, 1988; Delagarde et al., 2011). In contrast, the negative MR $(-0.90 \mathrm{~kg}$ of milk per $\mathrm{kg}$ DM of supplement) observed at the high PA contradicts the results of previous studies where, at a high PA, the change in the MR due to corn silage supplementation varied from 0.1 to $0.7 \mathrm{~kg}$ per $\mathrm{kg}$ of supplemental DM consumed (Moran and Stockdale, 1992; Stockdale, 1996; Pérez-Prieto et al., 2011; Miguel et al., 2014). However, this result is supported by the high SR (1.35), which indicates there was low motivation for grazing after the consumption of corn silage, which affected the pasture intake rate of the supplemented cows. The effect of silage supplementation on the motivation to graze has been previously observed (Phillips and Leaver, 1985; Pérez-Prieto et al., 2011). When grazing cows are supplemented with corn silage, a reduction in the PI is generally associated with a reduction in the PI rate ranging from 0.6 to $1.5 \mathrm{~g}$ $\mathrm{DM} / \mathrm{min}$ per $\mathrm{kg}$ of $\mathrm{DM}$ supplement intake (Phillips and Leaver, 1985; Graf et al., 2005; Pérez-Prieto et al., 2011). In the current study, the PI rate decreased by 0.7 and $2.3 \mathrm{~g} \mathrm{DM} / \mathrm{min}$ per $\mathrm{kg}$ of DM corn silage intake at the low and high PA, respectively, which supports the conclusion that the loss of motivation to graze in cows caused by corn silage supplementation is greater at the high PA than at the low PA.

\section{CONCLUSION}

Annual ryegrass pastures had a specific structure that made it difficult for the cows to achieve their full potential intake, even at a high PA. In these conditions, corn silage supplementation improves the total DM intake and milk production of dairy cows grazing on temperate annual pastures, but only at a low PA. At a high PA, supplemented cows increased their SR due to a greater loss in the motivation to graze.

\section{ACKNOWLEDGEMENTS}

The authors are grateful to the Conselho Nacional de Desenvolvimento Científico e Tecnológico (CNPq/Brazil), Coordenação de Aperfeiçoamento de Pessoal de Nível Superior (CAPES/Brazil), Fundação de Amparo à Pesquisa e Inovação do Estado de Santa Catarina (FAPESC/Brazil) and UDESC (PAP/2017 TR 676) for financial support and grants.

\section{REFERENCES}

'T MANNETJE, L. Measuring biomass of grassland vegetation. In: 'T MANNETJE, L.; JONES, R. M. (Eds.). Field and laboratory methods for grassland and animal production research. Wallinford: CAB International, 2000. p.151-177.

ALIMENTATION des bovins, ovins et caprins: Besoins des animaux-Valeurs des aliments. Versailles: INRA, 2007.

BARRETT, P.D.; LAIDLAW, A.S.; MAYNE, C.S. et al. Pattern of herbage intake rate and bite dimensions of rotationally grazed dairy cows as sward height declines. Grass Forage Sci., v.56, p.362-373, 2001.

BARTH NETO, A.; CARVALHO, P.C.F.; LEMAIRE, G. et al. Perfilhamento em pastagens de azevém em sucessão a soja ou milho, sob diferentes métodos e intensidades de pastejo. Pesqui. Agropecu. Bras., v.48, p.329-338, 2013.

BARTH NETO, A.; SAVIAN, J.V.; SCHONS R.M.T. et al. Italian ryegrass establishment by self-seeding in integrated crop-livestock systems: effects of grazing management and crop rotation strategies. Eur. J. Agron., v.57, p.77-83, 2014.

DELABY, L.; PEYRAUD, J.L.; DELAGARDE R. Production des vaches laitières au pâturage sans concentré. Rencontres Recherche Ruminants, v.6, p.123-126, 1999. 
DELAGARDE, R.; FAVERDIN, P.; BARATTE, C. et al. GrazeIn: a model of herbage intake and milk production for grazing dairy cows. 3 . Simulations and external validation of the model. Grass Forage Sci., v.66, p.61-77, 2011.

DELAGARDE, R.; PRACHE, S.; D'HOUR, P. et al. Ingestion de l'herbe par les ruminants au pâturage. Fourrages, v.166, p.189-212, 2001.

DUCHINI, P.G.; GUZATTI, G.C.; RIBEIROFILHO, H.M.N. et al. Tiller size/density compensation in temperate climate grasses grown in monoculture or in intercropping systems under intermittent grazing. Grass Forage Sci., v.69, p.655-665, 2014.

GRAF, C.M.; KREUZER, M.; DOHME, F. Effects of supplemental hay and corn silage versus full-time grazing on ruminal $\mathrm{pH}$ and chewing activity of dairy cows. J. Dairy Sci., v.88, p.711-725, 2005.

HERNANDEZ-MENDO, O.; LEAVER, J.D. Effect of replacing time available for grazing with time available for eating maize silage and soyabean meal on milk yield and feeding behaviour in dairy cows. Grass Forage Sci., v.59, p.318-330, 2004.

HERRERO, M.; THORNTON, P.K.; NOTENBAERT, A.M. et al. Smart investments in sustainable food production: revisiting mixed crop-livestock systems. Science, v.327, p.822$825,2010$.

JONES, B.; KENWARD, M.G. Design and Analysis for three or more treatments. In: COX, D.R.; HINKLEY, D.V.; RUBIN, D. et al. (Eds.). Monographs on statistics design and applied probability. London: Chapman and Hall, 1989. p.189-241. (no.34).

MAYES, R.W.; LAMB, C.S.; COLGROVE, P.M. The use of dosed an herbage n-alkanes as markers for determination of herbage intake. $J$. Agric. Sci., v.107, p.161-170, 1986.

MERTENS, D.R. Gravimetric determination of amylase-treated neutral detergent fibre in feeds with refluxing beakers or crucibles: a collaborative study. J. AOAC Int., v.85, p.12171240, 2002.
MIGUEL, M.F.; RIBEIRO-FILHO, H.M.N.; ANDRADE, E.A. et al. Pasture intake and milk production of dairy cows grazing annual ryegrass with or without corn silage supplementation. Anim. Prod. Sci., v.54, p.1810-1816, 2014.

MIGUEL, M.F.; RIBEIRO-FILHO, H.M.N.; CRESTANI, S. et al. Pasture characteristics of italian ryegrass and milk production under different management strategies. Pesqui. Agropecu. Bras., v.47, p.863-868, 2012.

MOATE, P.J.; ROGERS, G.L.; ROBINSON, I.B. Effect of level of silage supplement and pasture allowance on pasture intake, milk yield and milk composition of grazing cows. Anim. Prod. Aust., v.15, p.722, 1984.

MORAN, J.B.; STOCKDALE, C.R. Maize silage for the pasture-fed dairy cow 1 . Effect of level of silage feeding, and responses to cottonseed meal while grazing perennial pastures in the spring. Aust. J. Exp. Agric., v.32, p.279285, 1992.

OFFICIAL methods of analysis. 16.ed. Virginia, USA: Association of Official Analytical Chemists, 1997.

PÉREZ-PRIETO, L.A.; DELAGARDE， R. Meta-analysis of the effect of pregrazing pasture mass on pasture intake, milk production, and grazing behaviour of dairy cows strip-grazing temperate grasslands. J. Dairy Sci., v.95, p.53175330, 2012.

PÉREZ-PRIETO, L.A.; PEYRAUD, J.L.; DELAGARDE, R. Substitution rate and milk yield response to corn silage supplementation of late-lactation dairy cows grazing low-mass pastures at 2 daily allowances in autumn. $J$. Dairy Sci., v.94, p.3592-3604, 2011.

PEYRAUD, J.L.; DELAGARDE, R. Managing variations in dairy cow nutrient supply under grazing. Animal, v.7, p.57-67, 2013.

PHILLIPS, C.J.C. The use of conserved forage as a supplement for grazing dairy cows. Grass Forage Sci., v.43, p.215-230, 1988.

PHILLIPS, C.J.C.; LEAVER, J.D. Supplementary feeding of forage to grazing dairy cows. 2. Offering grass silage in early and late season. Grass Forage Sci., v.40, p.193-199, 1985. 
RIBEIRO-FILHO, H.M.N.; DELAGARDE, R.; PEYRAUD, J.L. Herbage intake and milk yield of dairy cows grazing perennial ryegrass swards or white clover/perennial ryegrass swards at lowand medium-herbage allowances. Anim. Feed Sci. Tech., v.119, p.13-27, 2005.

RIBEIRO-FILHO, H.M.N.; HEYDT, M.S.; BAADE, E.A.S. et al. Consumo de forragem e produção de leite de vacas em pastagem de azevém-annual com duas ofertas de forragem. Rev. Bras. Zootec., v.38, p.2038-2044, 2009.

RIBEIRO-FILHO, H.M.N.; SETELICH, E.A.; CRESTANI, S. et al. Relationship between diurnal grazing time and herbage intake in dairy cows in rotational grazing. Cienc. Rural, v.41, p.2010-2013, 2011.
RUSSELE, M.P.; ENTZ, M.H.; FRENZLUEBBERS, A.J. Reconsidering integrated crop-livestock systems in North America. Agron. J., v.99, p.325-334, 2007.

STATISTICAL analysis system. Version 9.1. Cary: SAS, 1999.

STOCKDALE, C.R. Substitution and production responses when lactating dairy cows graze white clover pasture supplemented with maize silage. Aust. J. Exp. Agric., v.36, p.771-776, 1996. 